\title{
Effect Fresh Milk on Surface Roughness of Resin Modified Glass Ionomer Cement
}

\author{
Efek Susu Segar Terhadap Kekasaran Permukaan \\ Semen Ionomer Kaca Modifikasi Resin
}

\author{
Astrid Yudhit*, Kholidina Imanda Harahap, Yuli Ratna Dewi \\ Department Dental Material and Technology, \\ Faculty of Dentistry, Universitas Sumatera Utara \\ *Corresponding Author: yudhitprasetya@gmail.com
}

\begin{abstract}
Resin modified glass ionomer cement as restorative material used in dentistry especially in primary teeth. Fresh milk is often consumed by children as daily drink and it contains lactic acid and some other acid cause low pH. It was reported that low $\mathrm{pH}$ of beverages result a changes in dental restorations roughness. The aim of this study was to evaluate the change of surface roughness of resin modified glass ionomer cement after immersed in fresh milk for 2, 4, and 6 hours. Samples were disc shape resin modified glass ionomer cement with size $5 \mathrm{~mm}$ in diameter and $2 \mathrm{~mm}$ in thickness. Totally 24 samples were divided into 3 groups treatment, $(n=8)$, one group was immersed for 2 hours, others groups were immersed for 4 hours, and 6 hours. Fresh milk was pure cow's milk that obtained from the local farm. Surface roughness measurements was done before and after immersed by using a profilometer (Surfcorder SE-300, Laboratory Ltd, Japan). Results showed surface roughness's were changed as much as $0.0217 \pm 0.005 \mu \mathrm{m}$ for 2 hours immersed group, $0.0366 \pm$ $0.006 \mu \mathrm{m}$ for 4 hours immersed group, and $0.0555 \pm 0.004 \mu \mathrm{m}$ for 6 hours immersed group. One Way Anova test showed a significant differences between groups $(\mathrm{p}<0.05)$. It can be concluded that there was significant increased on surface roughness changes of modified resin ionomer cement after immersed in fresh milk for 2, 4 and 6 hours
\end{abstract}

Keywords: Resin modified ionomer cement, surface roughness, fresh milk

Semen ionomer kaca modifikasi resin sebagai bahan restorasi yang digunakan dalam kedokteran gigi terutama di gigi sulung. Susu segar sering dikonsumsi oleh anak-anak sebagai minuman harian dan mengandung asam laktat dan beberapa asam lainnya menyebabkan $\mathrm{pH}$ rendah. Dilaporkan bahwa $\mathrm{pH}$ minuman yang rendah menyebabkan perubahan kekasaran restorasi gigi. Tujuan dari penelitian ini adalah untuk mengevaluasi perubahan kekasaran permukaan semen ionomer kaca modifikasi resin setelah direndam dalam susu segar selama 2, 4, dan 6 jam. Sampel adalah resin bentuk gelas ionomer kaca yang dimodifikasi dengan ukuran diameter $5 \mathrm{~mm}$ dan tebal $2 \mathrm{~mm}$. Total 24 sampel dibagi menjadi 3 kelompok pengerjaan, $(n=8)$, satu kelompok direndam selama 2 jam, kelompok lain direndam selama 4 jam, dan 6 jam. Susu segar adalah susu sapi murni yang diperoleh dari peternakan setempat. Pengukuran kekasaran permukaan dilakukan sebelum dan sesudah direndam dengan menggunakan profilometer (Surfcorder SE-300, Laboratory Ltd, Jepang). Hasil penelitian menunjukkan kekasaran permukaan diubah sebanyak 0,0217 $\pm 0,005 \mu \mathrm{m}$ untuk kelompok rendaman 2 jam, $0,0366 \pm 0,006 \mu \mathrm{m}$ untuk kelompok rendaman 4 jam, dan 0,0555 $\pm 0,004 \mu \mathrm{m}$ untuk kelompok rendaman 6 jam. Uji One Way Anova menunjukkan perbedaan yang signifikan antar kelompok ( $\mathrm{p}<0,05)$. Dapat disimpulkan bahwa ada peningkatan yang signifikan terhadap perubahan kekasaran permukaan semen ionomer resin termodifikasi setelah direndam dalam susu segar selama 2, 4 dan 6 jam.

Kata Kunci: Semen ionomer kaca modifikasi resin, kekasaran permukaan, susu segar

\section{INTRODUCTION}

Resin modified glass ionomer cement was developed to overcome glass ionomer cement sensitivity to water during initial hardening by inserting resin monomers into a solution of polyacrylic acid. The main resin incorporated in the resin modified glass ionomer cement is a hydrophilic monomer such as 2-hydroxyethyl methacrylate (HEMA). Small amounts of dimethacrylate monomers can be combined to form poly-HEMA crosslinks during polymerization. ${ }^{1,2}$ Resin modified glass ionomer ce- 
ment was a popular restorative material that used in children due to it has benefit like fluoride released and easy in handling.

In oral cavity, dental restorations are often exposed to our diet like food and beverages. Previous studies had reported the effect of several diets on dental restoration properties. It was reported carbonated beverages $^{3}$, yogurt ${ }^{4}$, and infused water ${ }^{5}$ had effect on the surface roughness of conventional GIC. Surface roughness is a form of irregularity of the surface material. In oral cavity, the existence of surface roughness in restoration can accelerate bacterial colonization and maturation of dental plaque that can potentially increase the risk of oral, gingival irritation, and reduce aesthetics. Furthermore, at some point these would degraded the restoration itself. ${ }^{3,5,5}$

Fresh milk like cow's milk is one of the drinks that are often consumed daily by children. Cow's milk is derived from the milking of dairy cows, the natural content is not reduced or increased to anything and has not received any treatment. Cow's milk has low acidic properties with a $\mathrm{pH}$ value of $6.5-6.8 .^{7,8}$ The acids contained in most of the milk is lactic acid and others like, citric acid compounds, amino acids and milk-soluble carbon dioxide. ${ }^{7}$

Therefore, we interested to evaluate the effect of fresh milk. We use cow's milk in this study on surface roughness of resin modified glass ionomer cement after immersed for 2,4 and 6 hours. The duration were the accumulated exposure time of restoration material resin modified glass ionomer cement with cow's milk for 1, 2 and 3 months (in consumption estimation of milk 2 minutes per day).

\section{MATERIALS AND METHODS}

This was a laboratory experimental study with preand post-test group design. Samples were disc shape resin modified glass ionomer cement (Fuji 2 LC, GC Corp, Japan) with size $5 \mathrm{~mm}$ in diameter and $2 \mathrm{~mm}$ in thickness. Totally 24 samples were divided into 3 groups $(n=6)$, group immersed for 2 hours, group immersed for 4 hours, and group immersed for 6 hours.

The fresh milk that used in this study was a cow's milk from a local farmer in Medan, Sumatera Utara, Indonesia, which are freshly harvest in the morning. Then the $\mathrm{pH}$ of fresh milk was measured with $\mathrm{pH}$ meter and it showed the $\mathrm{pH}$ was 5.873.

Powder and liquid were placed on a paper pad with ratio of powder to liquid ratio $3.2 \mathrm{~g}: 1.0 \mathrm{~g}$ (according to manufacturer's instructions) and mixed until homogeny for 30 seconds. The admixed placed in the master cast and pressed with a load of $1 \mathrm{~kg}$ for $25 \mathrm{se}-$ conds. We used celluloid strips on the bottom and top of master cast. Then, the samples were light cured for 20 seconds on top and bottom of it. and illuminated for 20 seconds. The samples then stored in dark container for 24 hours until used.

Samples were immersed in $10 \mathrm{ml}$ of fresh cow's milk and kept in an incubator at $37^{\circ} \mathrm{C}$ for 2,4 and 6 hours.

Surface roughness measurements were measured before and after immersion using a profilometer (Surfcorder SE-300, Laboratory Ltd, Japan). Each specimen was measurement on 2 area points $( \pm 1$ $\mathrm{mm}$ from the edge of the sample). The surface roughness value of each sample was record and averages. The data (surface roughness change) was the mean differences between before and after the averages value of surface roughness.

One Way Anova test with Least Significance Difference (LSD) test were used to analyze the differences of surface roughness changes between groups.

\section{RESULTS}

Result showed the surface roughness changes of resin modified glass ionomer cement after immersion for 2, 4, and 6 hours in fresh cow's milk were $0.0217 \pm 0.005 \mu \mathrm{m}, 0.0366 \pm 0.006 \mu \mathrm{m}$, and 0.0555 $\pm 0.004 \mu \mathrm{m}$, respectively as shown in Table 1 .

Table 1. Mean and SD of surface roughness changes of resin modified glass ionomer cement after immersed in fresh milk for 2, 4, and 6 hours.

\begin{tabular}{cccc}
\hline Groups & $\mathrm{n}$ & $\begin{array}{c}\text { Surface roughness } \\
\text { changes }(\bar{x}) \pm \mathrm{SD}(\mu \mathrm{m})\end{array}$ & $\mathrm{p}$ \\
\hline $2 \mathrm{~h}$ & 8 & $0.0217 \pm 0.005$ & \\
\cline { 1 - 3 } $4 \mathrm{~h}$ & 8 & $0.0366 \pm 0.006$ & $\begin{array}{c}0.000 \\
*\end{array}$ \\
\hline $6 \mathrm{~h}$ & 8 & $0.0555 \pm 0.004$ & \\
\hline
\end{tabular}

* Significant differences, One Way Anova $(\mathrm{p}<0.005)$

One Way Anova test showed a significant differences $(\mathrm{p}<0.00)$ between all groups with $\mathrm{p}=0.00$. It was mean that there were a significant changes of surface roughness after immersed in fresh milk for 2,4, and 6 hours and the surface roughness were increased. Post hoc LSD showed that there were significant differences $(\mathrm{p}<0.00)$ between group 2,4 , and 6 hours. These mean that there was an increase of surface roughness over times, the longer duration of immersion, the more roughness its surface. 


\section{DISCUSSION}

The results of this study indicate that there was a change in surface roughness of resin modified glass ionomer cement after immersed in fresh cow's milk. The surface roughness of resin modified glass ionomer cement showed an increase after immersed in fresh cow's milk for 2, 4, and 6 hours. This might be due to low $\mathrm{pH}$ of the cow's milk $(\mathrm{pH}=5.873)$ and the absorption of water by resin modified glass ionomer cement. Previous study reported that there was an increase on the surface roughness of resin modified glass ionomer cement after immersed in infused water which had a low $\mathrm{pH}^{5}$

Fresh milk contains acid lactic and water that had effect on resin modified glass ionomer cement. In acidic environment, the hydrogen ion $\left(\mathrm{H}^{+}\right)$will be ionized and released, then $\mathrm{H}^{+}$ion will diffuses into the resin modified glass ionomer cement. This ion will replaces the metal cations in the matrix cement and form a cross link with polyalkenoate chain of resin modified glass ionomer. When the entire carboxyl acid group had ionized, the polymer chain will fulfill with $\mathrm{H}^{+}$ions and form a strong bond. These will make the metal ions $\left(\mathrm{Ca}^{2+}\right.$ and $\left.\mathrm{Al}^{3+}\right)$ which are one of the important part of resin modified glass ionomer cement structure, loss they bind. Furthermore,

\section{REFERENCES}

1. Kim YK, Kim KH, Kwon TY. Setting reaction of dental resin-modified glass ionomer restorative as a function of curing depth and postirradiation time. J. Spectrosc 2015; 2015: 1-8.

2. Yuliarti RT, Suwelo IS, Soemartono SH. Kandungan unsur fluor pada email gigi tetap muda dengan tumpatan semen ionomer kaca viskositas tinggi. Ind J Dent 2008; 15(2): 163-8.

3. Diansari V, Ningsih DS, Moulinda C. Evaluasi kekasaran permukaan glass ionomer cement (GIC) konvensional setelah perendaman dalam minuman berkarbonasi. Cakradonya Dent J 2016; 8(2): 11116.

4. Ningsih DS, Fitriany S, Rahmita R. Perendaman semen ionomer kaca setelah direndam dalam yoghurt. Dent Mater J 2014; 5(2): 64-8.

5. Kurniawati AC, Tjandrawinata R. Pengaruh perendaman infused water dan penyikatan gigi terhadap kekasaran permukaan semen ionomer kaca modifikasi resin. JMKG. 2014; 3 (2): 67-74.

6. Beresescu $G$ and Brezeanu LC. Effect of artificial saliva on the surface roughness of glass-ionomer cements. AMSET 2011; 8 (2): 134-6.

7. Harjanti DW, Yudhonegoro RJ, Sambodho, Nurwantoro. Evaluasi susu segar di kabupaten Klaten. Agromedia 2016; 34(1): 8-14. the less metal cations in the matrix, the more ions taken and release from the surface of the glass parmatrix. These will degrade the surface and weaken the cement. ${ }^{4,5,6,9}$ In this study, as a result the surface roughness was increased over time.

Water had effect on resin, as called water sorption phenomena. Resin modified glass ionomer contain HEMA. These HEMA is hydrophilic component that can increase the absorption of water. Water in fresh milk will penetrate into the cement surface and will cause a reaction between $\mathrm{OH}^{-}$ions with silica ions in cement and further reaction will cause the silica particle detached. As result, the surface of the resin modified glass ionomer cement becomes poreus and more rough. ${ }^{9,1}$

It can be concluded that fresh milk had effect on surface roughness of resin modified glass ionomer cement. Surface roughness of resin modified glass ionomer will increased over time, longer immersion will increased the surface roughness of resin modified glass ionomer cement.

With the limitation of this study, further investigation is needed to determine the exact cause of the change over the surface roughness of resin modified glass ionomer cement after immersion in fresh cow milk.

8. Kencanawati AP, Suprayogi TH, Sayuthi SM. Total plate count and $\mathrm{pH}$ of fresh milk of dairy cows after dipping using iodosphor solution as desinfectant on different duration's dime. Anim Agricult J 2015; 4(1): 127-31.

9. Permatasari AP, Nahzi MYI, Widodo. Kekasaran permukaan resin modified glass ionomer cement setelah perendaman dalam air sungai. Dentino 2016; 1(2) : 164-8.

10. Ratner BD. Classes of materials used in medicine. In: Ratner BD, Hoffman AS. Biomaterial science an introduction to materials in medicine. California: Academic Press, 1996: 153-61. 